\title{
Relationship between Venture Capital and Enterprises' Performance of GEM Listed Companies
}

\author{
Jianguo Wang ${ }^{1 . *}$, Jun $\mathrm{Wu}^{1}$ and Guomin $\mathrm{Ji}^{1}$ \\ ${ }^{1}$ School of Management, Harbin Institute of Technology, Harbin, China \\ Corresponding Email: 490782424@qq.com
}

\begin{abstract}
With the Growth Enterprise Market (GEM) opening, China's capital market system has been gradually improved, the total amount of venture capital investment has emerged explosive growth. This article focused on relationship between venture capital and enterprises' performance of GEM listed companies in China. The empirical results found that venture capital involvement will enhance enterprises' performance, a high proportion of venture capital holdings is conducive to enhancing enterprises' performance, and the high reputation of venture capital institution is able to enhance enterprises' performance.
\end{abstract}

\section{Introduction}

In the current GEM market, the percent of venture-backed companies is more than $70 \%$, which indicated that the venture capital playing an increasingly important role in the market, and also a growing number of venture capital involved in companies listed on the GEM indicates venture capital is playing an increasingly important role on hightech enterprises. Based on the study of venture capital and corporate performance from domestic and foreign, the article selected GEM companies to conduct empirical research.

Nahata [1] empirically studied the venture enterprises, and he found that the involvement of venture capital is helpful to improve the performance of enterprises. Especially, the reputation of venture capital institutions has a notable impact on the performance of the enterprise. In Krishnan's [2] study, the market share of the IPO enterprises invested by the venture capital institution is used to measure the reputation of the venture capital institution.

Cuifeng W. [3] examines the investment preference and pattern of venture capital firms, from the perspective of the investment preference, when the geographic distance between the venture capital firm and the entrepreneurial firm is shorter, or when the entrepreneurial firm has financial strength, the probability of the venture capital firm's investment will be higher. Xiangyu G. et al. [4] found that the UNDPRC of company invested by venture capital firms with foreign capital and mixed type background is lower than that of the state owned company, and the stock return rate is higher when the company fist IPO. Wei Z. [5] investigated the relationship between venture capital and the performance of the strategic emerging industries listed companies in China. The empirical result shows that: Venture capital has significant inhibited effect on the strategic emerging industries listed companies. Hochberg's further research shows that the venture capital with high-shareholding and high-reputation can significantly improve the performance, while number of venture capital cannot. Bing L. [6] studied on the relationship between slack resources and firm performance in entrepreneurial firms with the sample of China GEM listed companies from the perspective of managerial discretion theory, and specifically focuses on how venture capital affects this relationship for post-IPO entrepreneurial firms.

\section{Instructions on sample data collection}

The article collected the explanatory variables that can reflect whether the venture capital is involved, the proportion of venture capital investment, reputation and combined venture capital investment. Venture capital intervention is defined as $\mathrm{VC}$, when there is a venture capital investment institution in the top ten shareholders of the enterprise, then VC $=1$, otherwise $\mathrm{VC}=0$, the proportion of venture capital is defined as $\mathrm{Shr}$, the proportion of venture capital investment is the sum of the proportion of the venture capital institutions in the top ten shareholders of the enterprise, reputation of venture capital was defined by Fame, in this paper, the Zero2IPO of the venture capital institutions ranked was chosen for judgment, when the venture capital investment institutions ranked in the top fifty, it means the venture capital investment institutions has high reputation, then Fame $=1$, otherwise Fame $=0$, joint investment is defined as Comb, when the current ten major shareholders of the companies have two or more venture capital investment institutions, $\mathrm{Comb}=1$, otherwise Comb $=0$. 
And also the article collected the explained variable that can reflect the enterprise's performance. Performance of enterprises is reflected in four dimensions., they are the profitability of the enterprise, the operating ability, the development ability and the innovation ability which can be measured by the net assets income rate (ROE), total assets turnover rate (TOA), operating income growth rate (Growth) and R\&D revenue ratio (Ratio).

In addition, in order to be able to correctly study on relationship between venture capital and corporate performance, the article selected scale of sample firms (lnScale), equity concentration (Top1), financial leverage (Lev) and cash flow of operation (Cfo) as control variables.

The article chose data of Shenzhen GEM listed companies from 2009 to 2013 . According to the relevant provisions of the securities law of PRC: shares held by other shareholders of the company at the time of the IPO since the date listed on the 12 months shall not be transferred, so within 12 months after the IPO companies won't have venture capital exit, therefore this article selected empirical data of Shenzhen GEM listed companies in the year of 2009-2013, and the research eliminated companies that lack data.

\section{Descriptive analysis of the model designed and statistical analysis of variables}

In this article, Gompers' research method was used to analyse the relationship between venture capital and its characteristics and company's performance. The empirical study was took by two steps, in the first part, the influence of venture capital on firm performance was studied, and the model 1 is as follows.

$$
R O E=C+\beta_{1} V C+\beta_{2} \text { lnScale }+\beta_{3} \text { Top } 1+\beta_{4} \text { Lev }+\beta_{5} C f o+\varepsilon
$$

In the second part, the influence of characteristics of venture capital and the proportion of venture capital was studied, and the model 2 is as follows.

$$
R O E=C+\beta_{1} \text { State }+\beta_{2} \text { Fame }+\beta_{3} \text { Shr }+\beta_{4} \text { Comb }+\beta_{5} \operatorname{lnScale}+\beta_{6} \text { Top } 1+\beta_{7} L e v+\beta_{8} \text { Cof }+\varepsilon
$$

$C$ is intercept, $\beta_{I}-\beta_{5}$ is coefficient, $\varepsilon$ is residual, the rest are interpreted variables, explanatory variables, and control variables.

SPSS and Stata statistical software were used for empirical research. Descriptive statistics of the sample population can be seen from table 1. It mainly analyses the maximum, minimum, mean and standard deviation of the venture capital intervention and the enterprise performance, table 1 shows that Venture Capital Holdings accounts for $72 \%$ of the Sample Firms, which means that the risk of investment in China's GEM Listing Companies play an important role.

\begin{tabular}{|c|c|c|c|c|c|}
\hline & $\mathrm{N}$ & Min & Max & Mean & SD \\
\hline ROE & 326 & .0031 & .2817 & .1252 & .04214 \\
\hline TOA & 326 & .131 & 1.8568 & .5674 & .24565 \\
\hline Growth & 326 & -1.0642 & .5634 & .1505 & .21322 \\
\hline Ratio & 326 & $0 \Omega \Omega$ & 3.3800 & .0729 & .19298 \\
\hline $\mathrm{VC}$ & 326 & 104010 & 1.0000 & .7209 & .44927 \\
\hline lnScale & 326 & $\begin{array}{r}19.4910 \\
0877\end{array}$ & 22.4975 & 20.6127 & .506208 \\
\hline Top1 & 326 & 0110 & .6887 & .33938 & .127021 \\
\hline Lev & 326 & & .5255 & .15255 & .105756 \\
\hline Cfo & 326 & $3.708 \mathrm{E} 8$ & $6.2386 \mathrm{E} 8$ & $1.541 \mathrm{E} 7$ & 7.726E7 \\
\hline
\end{tabular}

Table 1. Descriptive Analysis of Sample.

Table 2. Descriptive statistics on the classification of venture capital investment.

\begin{tabular}{|c|c|c|c|c|c|c|}
\hline & \multicolumn{2}{|c|}{$\mathrm{N}$} & Min & Max & Mean & SD \\
\hline \multirow{2}{*}{ ROE } & VC & 235 & .0031 & .2817 & .129403 & .0440708 \\
& non VC & 91 & .0491 & .2164 & .127263 & .0368133 \\
\multirow{3}{*}{ TOA } & VC & 235 & .1316 & 1.8568 & .558272 & .2322009 \\
& non VC & 91 & .1791 & 1.7395 & .530803 & .2774084 \\
& VC & 235 & -1.0642 & .5634 & .191316 & .2229609 \\
Growth & non VC & 91 & -.7855 & .5495 & .148495 & .1868492 \\
& VC & 235 & .0030 & 3.3800 & .105940 & .2248443 \\
Ratio & non VC & 91 & .0160 & .3990 & .065433 & .0505320 \\
& VC & 235 & 19.4910 & 22.4975 & 20.620855 & .5071598 \\
TnScale & non VC & 91 & 19.5314 & 21.7827 & 20.591565 & .5059252 \\
& VC & 235 & .0891 & .6887 & .345106 & .1245387
\end{tabular}




\begin{tabular}{|c|c|c|c|c|c|c|} 
& non VC & 91 & .0877 & .6148 & .324582 & .1327767 \\
Lev & VC & 235 & .0110 & .4471 & .151817 & .1010311 \\
& non VC & 91 & .0126 & .5255 & .154438 & .1174643 \\
\multirow{2}{*}{ Cfo } & VC & 235 & $-3.7086 \mathrm{E} 8$ & $6.2386 \mathrm{E} 8$ & $1.606858 \mathrm{E} 7$ & $8.1381779 \mathrm{E} 7$ \\
& non VC & 91 & $-2.3034 \mathrm{E} 8$ & $2.1214 \mathrm{E} 8$ & $1.370103 \mathrm{E} 7$ & $6.5829932 \mathrm{E} 7$ \\
\hline
\end{tabular}

As can be seen from table 2, venture capital invested enterprises' return on equity (ROE) and total asset turnover (TOA) mean are higher than the non-venture capital firms, the difference between them is not too much. Venture capital invested enterprises' average operating income growth rate (Growth) and R\&D income ratio (Ratio) were higher than the values of the non-venture investment enterprises, respectively, higher than $5 \%$ and $4 \%$, by comparing the venture and non-venture invested enterprise, the involvement of venture capital on enterprise performance has certain influence. In terms of scale of the enterprise (lnScale), venture investment enterprises average scale is higher than non-venture investment enterprises, which is consistent with the theory, because compared to non-venture enterprises, the venture investment enterprises can get financing from venture capital, and the scale of investment is relatively large. In terms of assets and liabilities rate (Lev), compared with non-venture investment enterprises, the venture capital invested enterprises' assets and liabilities rate levels were lower, the reason is that the GEM listed companies are generally high and new technology enterprises, due to their uncertainty development, it is very hard for them to obtain funds through traditional banks and other financial institutions, therefore, the assets and liabilities rate is lower. Cash flow of operation (Cfo) of the venture investment enterprises is higher, this is because the venture capital means a kind of rights and interests, venture capital investors can not only provide funds for the enterprises, but also provide their own professional knowledge and investment experience, which are helpful to improve management level of enterprises they invested, the cash flows from operating activities is the main source of cash, it can represent enterprise's operation and management level.

Table 3. Correlation analysis of venture investment intervention.

\begin{tabular}{|c|c|c|c|c|c|}
\hline & VC & lnScale & Top1 & Lev & Cfo \\
\hline & 1 & & & - & .014 \\
VC & .026 & .026 & .073 & .011 & .142 \\
InScale & .073 & 1 & -.014 & .173 & .073 \\
Top1 & - & -.014 & 1 & .043 & - \\
Lev & .011 & .173 & .043 & 1 & .323 \\
Cfo & .014 & .142 & .073 & - & 1 \\
& & & & .323 & \\
\hline
\end{tabular}

Table 3 shows that the partial correlation coefficient between the independent variables and control variables absolute most are less than 0.3 , and the partial correlation coefficient that less than 0.2 accounted for $90 \%$, which indicates that there is no significant correlation between venture capital and other control variables in the model designed, and regression analysis can be carried out.

Table 4 shows the correlation analysis of characteristic variables of venture capital, there is no significant correlation between variables and control variables.

Table 4. Correlation analysis of characteristic variables of venture capital.

\begin{tabular}{|c|c|c|c|c|c|c|c|c|}
\hline & Shr & Comb & Fame & State & lnScale & Top1 & Lev & Cfo \\
\hline Shr & 1 & .374 & .030 & $\begin{array}{c}- \\
.154\end{array}$ & .139 & .043 &.$\overline{-} .034$ & .188 \\
\hline Comb & .374 & 1 & .207 &.$\overline{-} .036$ & .080 & .011 & .035 & .012 \\
\hline Fame & .030 & .207 & 1 & .182 & .035 & -.114 & .052 & $\begin{array}{c}- \\
.070\end{array}$ \\
\hline $\operatorname{lnScale}$ & .139 & .080 & .035 & 007 & 1 & .008 & .179 & .131 \\
\hline Top1 & .043 & .011 & -.114 & $\overline{124}$ & .008 & 1 & .096 & .089 \\
\hline Lev & $\overline{-} .034$ & .035 & -.052 & .013 & .179 & .096 & 1 &.$\overline{-}$ \\
\hline Cfo & .188 & 012 & -.070 & $\begin{array}{c}- \\
.071 \\
\end{array}$ & .131 & .089 &.$-\overline{203}$ & 1 \\
\hline
\end{tabular}




\section{Regression analysis on relationship between venture capital and enterprises' performance}

\subsection{Regression of venture capital intervention on enterprises' performance}

Regression of venture capital intervention on enterprises' performance was shown in table 5, the involvement of venture capital has an impact on corporate performance. The R2 were $0.355,0.445,0.148,0.324$, the adjusted R2 were 0.327 , $0.412,0.112,0.309$, the model fit was better and the Sig. value has passed the significant test.

According to table 5, venture capital intervention has positive effect on firms' performance, the $t$ values of venture capital on ROE, growth and Ratio were 2.321, 196.2, 1.951 in 10\% level, it means that the three variables all reached the significant level, on the other hand, the t value of regression analysis of the venture capital on TOA has not reached the significant level, but they were positively correlated. Through the analysis, it can be concluded that venture capital has a positive effect on firms' performance, the enterprises with venture capital always perform better than those without venture capital.

Table 5. Regression of venture capital intervention on firms' performance.

\begin{tabular}{|c|c|c|c|c|}
\hline & ROE & TOA & Growth & Ratio \\
\hline VC & $0.003 * *$ & 0.032 & $0.001^{*}$ & $1.315^{*}$ \\
& $(2.321)$ & $(1.112)$ & $(1.962)$ & $(1.951)$ \\
lnSca. & -0.006 & $-0.072 * *$ & 0.029 & $-1.558^{*}$ \\
& $(-1.273)$ & $(-2.773)$ & $(1.178)$ & $(-1.948)$ \\
Top1 & 0.006 & $0.165^{*}$ & 0.064 & $-15.167 *$ \\
& $(0.396)$ & $(1.939)$ & $(0.679)$ & $(-1.984)$ \\
Lev & $0.007 *$ & $0.807 * * *$ & $0.028 * *$ & $-16.592 *$ \\
& $(1.961)$ & $(6.166)$ & $(2.428)$ & $(-1.949)$ \\
Cfo & $0.008^{* * *}$ & -0.000 & 0.000 & 0.000 \\
& $(4.923)$ & $(-1.467)$ & $(0.384)$ & $(0.442)$ \\
Inter. & $0.239 * * *$ & 1.903 & $-0.469 *$ & 46.048 \\
& $(5.106)$ & $(0.419)$ & $(-1.938)$ & $(1.024)$ \\
\hline r2 & 0.355 & 0.445 & 0.148 & 0.324 \\
r2_a & 0.327 & 0.412 & 0.112 & 0.309 \\
F & 5.495 & 10.874 & 2.485 & 4.565 \\
Sig. & .000 & .000 & .087 & .017 \\
\hline
\end{tabular}

\subsection{Regression of characteristics of venture capital}

Regression of characteristics of venture capital shows in table 6, the venture capital investment shareholding ratio (Shr) has a positive effect on the performance of the enterprise. The venture capital investment is an equity investment, in order to realize the value of capital, it will use its own experience and expertise to provide added services to the invested companies, which can promote the improvement of enterprise performance. The fame of venture capital institutions has positive effect on firms' performance, the impact of the fame of venture capital institutions on ROE and Growth is significant at the $10 \%$ level, and the impact on R\&D is significant at the $5 \%$ level, the fame of venture capital institutions also has a positive impact on the TOA, but it is not as significant as the other indicators. Effect of combine investment on firms' performance is negative, the main reason can be explained that venture capital institutions want to take a free ride from each other.

Table 6. Regression of characteristics of venture capital.

\begin{tabular}{|c|c|c|c|c|}
\hline & ROE & TOA & Growth & Ratio \\
\hline \multirow{2}{*}{ Shr } & $0.015^{* *}$ & $0.003^{*}$ & $0.122^{*}$ & 0.005 \\
& $(2.957)$ & $(1.931)$ & $(1.949)$ & $(0.290)$ \\
\hline
\end{tabular}




\begin{tabular}{|c|c|c|c|c|}
\hline Comb & $-0.012^{*}$ & -0.003 & -0.040 & -0.007 \\
& $(-1.925)$ & $(-0.100)$ & $(-1.278)$ & $(-1.116)$ \\
Fame & $0.007^{*}$ & 0.033 & $0.008^{*}$ & $0.017^{* *}$ \\
& $(1.995)$ & $(1.358)$ & $(1.941)$ & $(2.427)$ \\
InSca. & -0.003 & -0.038 & $0.064^{* *}$ & -0.001 \\
& $(-0.557)$ & $(-1.306)$ & $(2.232)$ & $(-0.162)$ \\
Top1 & 0.020 & $0.268^{* *}$ & 0.123 & -0.036 \\
& $(0.886)$ & $(2.352)$ & $(1.071)$ & $(-1.574)$ \\
Lev & 0.042 & $0.676^{* * *}$ & 0.061 & $-0.136^{* * *}$ \\
& $(1.441)$ & $(4.538)$ & $(0.406)$ & $(-4.586)$ \\
Cfo & $0.000^{* * *}$ & -0.000 & 0.000 & 0.000 \\
& $(4.923)$ & $(-1.467)$ & $(1.315)$ & $(0.658)$ \\
Inter. & 0.185 & $1.157^{*}$ & - & 0.118 \\
& $(1.626)$ & $(1.966)$ & $1.193 * *$ & $(1.005)$ \\
& & & $(-2.021)$ & \\
\hline r2 & 0.148 & 0.160 & 0.062 & 0.166 \\
r2_a & 0.117 & 0.130 & 0.029 & 0.136 \\
F & 4.826 & 5.298 & 1.853 & 5.551 \\
Sig. & .000 & .000 & .0232 & .0394 \\
\hline
\end{tabular}

\section{Conclusion}

In this article, a data analysis for the venture capital investment and performance of the GEM companies is mainly conducted, by regression analysis, the following conclusions can be obtained.

\subsection{Intervention of venture capital investment contributes to the improvement of enterprises' performance}

Venture capital investment produces positive effect on firms' performance, indicating that as an equity investment the venture capital investment not only provides capital for the enterprises, but also increases their own value using their professional knowledge and experience, so that they can achieve their own asset appreciation.

\subsection{Proportion of venture capital investment has impact on enterprises' performance}

As the shareholders of the enterprises, venture capital investors concerned all aspects of the invested enterprises in order to realize their high return target. The good performance of the enterprise is the basis for the shareholders to obtain high returns. Therefore, the higher proportion of venture capital holdings of enterprise shares, the enterprise more likely to get operating guidance, so that it is possible for the venture capital to achieve their own investment income.

\subsection{Fame of venture capital institutions has a positive effect on enterprises' performance}

In order to establish a good reputation to make the venture capital later refinanced smoothly, they will make full use of their professional knowledge and experience to provide consulting guidance for the invested enterprises. And also, the venture capital with higher reputation is recognized by the market and has a certain market value, and they can get better performance.

\subsection{Combined venture capital has a negative influence on the invested enterprises' performance}

The main reason may be that although the combined investment of each venture capital institution has rich investment experience and resources, but each of them want to take a free rider, and they didn't give full play to their initiative, each of them expected to gain profit from other venture capital institutions. 


\section{References}

1. Nahata R. J. FINANC. ECON. 90, 2(2008)

2. Krishnan, C. N. V. , Ivanov, V. I. , Masulis, R. W. \& Singh, A. K. J. F. Q. A. 46, 5 (2011)

3. Cuifeng W. Shinong W. Wei L. N. K. Biz Rev. 17, 5(2014)

4. Xiangyu G. Yuhua L. F \& A. 1 (2014)

5. Wei Z. Jun W. Ind. Eco. Rep. 2 (2015)

6. Bing L. Chaoliang L. Zhengping F. Nan Kai Biz Rev. 19, 1 (2016) 